\begin{tabular}{|c|c|}
\hline \multirow{3}{*}{ 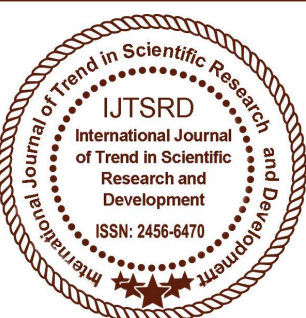 } & $\begin{array}{l}\text { International Journal of Trend in Scientific } \\
\text { Research and Development (IJTSRD) }\end{array}$ \\
\hline & International Open Access Journal \\
\hline & ISSN No: 2456 - 6470 | www.ijtsrd.com | Volume - 2 | Issue - 5 \\
\hline
\end{tabular}

\title{
Green Synthesis of Ferric Oxide Nano Particles Using Manilkara Zapota Plant Leaves and Study its Effect on Dyes in Textile Waste Water

\author{
Pratibha Singh $^{1}$, Dr. Bharat Nagar ${ }^{2}$ \\ ${ }^{1}$ Research Scholar, Jagannath University Jaipur, Rajasthan, India \\ ${ }^{2}$ Professor \& Head, Department of Civil Engineering, \\ ${ }^{2}$ Jagannath Gupta Institute of Engineering and Technology, Rajasthan, India
}

\begin{abstract}
Water is an essential requirement for all living creature for their survival. It is one of the vital components of natural environment. Out of various industries, textile contributes majorly in polluting water maily with hazardous dyes. In textile industry, chemical processing contributes about $70 \%$ tof pollution. At present treatment of dye present in textile waste water is of utmost importance. The present work is aimed at green synthesized ferric oxide nano particles by using Manilkara Zapota leaves extract in degradation of hazardous dyes like methylene blue which is confirmed by a decrease in absorbance maximum values. The formation of ferric oxide nano particles will be assessed using UV-Vis spectroscopy, SEM, TEM. The study is carried out on ferric oxide nanoparticles catalyst on reduction of hazardous dyes. Novelty of this present study is that the plant extract is very cost effective and eco friendly and thus can be economic and effective alternative for the large scale synthesis of iron nano particles.
\end{abstract}

Keywords: Iron nano particle; Plant extract; Characterization

\section{INTRODUCTION}

Water is an essential requirement for all leaving creature for their survival. It is one of the vital components of natural environment. Water resources are being used in human society for various purposes such as: irrigation, industrial purposes and in daily usage. However due to rapid urbanization, industrialization and population growth and increased agricultural activities water resources are under stress.
The availability of water of desired quality, its cost and the treatment of wastewater are growing areas of concern. Many industries like textile, refineries, chemical, plastic and food-processing plants produce wastewaters characterized by a perceptible content of organics (e.g. phenolic compounds) with strong color. For example, a typical textile dyeing process consists of desizing, scouring, bleaching, dyeing, finishing and drying operations. Except the last two stages, each operation is associated with rinsing step, requires large amount of water. In general, textile industries generate effluent at an average of $100-170 \mathrm{l} \mathrm{kg}^{-1}$ of cloth processed, which is characterized by strong color, high COD with wide variation in $\mathrm{pH}$.

The textile industry deals with the design and production of various fabrics such as yarn, cotton, wool, silk with a web of processes intertwined to produce the final product. The textile industry spans a spectrum of processes. This industry plays a crucial part in providing the society with basic needs. It is also important in the economic perspective, providing employment and high industrial output. Especially developing countries have high economic contribution from textile industries.

Textile industries consume large volumes of water and chemicals for wet processing of textiles. The chemical reagents used are very diverse in chemical composition, ranging from inorganic compounds to polymers and organic products (Mishra and Tripathy, 1993; Banat et al., 1996; Juang et al., 1996). 
Conventional methods for dealing with textile wastewater consist of various combinations of biological, chemical and physical methods (Babuna et al, 1999; Slokar et al, 1998). Textile wastewater is well known with its high chemical oxygen demand, strong color, large amount of suspended solids, variable $\mathrm{pH}$, salt content and high temperature. Therefore, the treatment systems combined with physical, biological and chemical methods become inefficient for the effective treatment of industrial textile wastewater due to the variation of wastewater characteristics and heavy COD load.

The intensity of pollution depends on the fabric, as well as dyes and chemicals used in textile industries, their fixation rate on the fabric. Beside that the dyeing sequence, dyeing equipment and the liquor ratio used in the textile industries can also affect the pollution intensity. Colored organic effluent is produced in industries such as textiles, rubber, paper, plastic, cosmetics, etc. Dyes are recognized as microtoxicants and their acute and short-term effects have long been recognized. As dyes are designed to resist breakdown with time and exposure to sunlight, water, soap, and oxidizing agent, they cannot be easily removed by conventional wastewater treatment processes due to their complex structure and synthetic origins. Thus, dye removal has been an important but challenging area of wastewater treatment.

Here we describe use of green synthesized ferric oxide nano particles in degradation of hazardous dyes like methylene blue. The ferric oxide nano particles used as nano catalyst will be synthesized using plant extract. The formation of ferric oxide nanoparticles will be assessed using UV-Vis spectroscopy, SEM, TEM. The study is carried out on ferric oxide nanoparticles catalyst on reduction of hazardous dyes, which is confirmed by a decrease in absorbance maximum values.

\subsection{NANOMATERIALS:}

Nanotechnology is an enabling technology that deals with nano meter sized materials in different field of science. It is the field of nanoscience, the phenomena applied on a nanometer scale level. Nano-materials are the smallest structures that humans have developed, having size of a few nanometers. More precisely, the nano-particles are those that have structure components with one dimension at least less than $100 \mathrm{~nm}$.
The simple and cheapest method of synthesis of nano materials is biological method from plants etc. Metals like silver, titanium, zinc, iron etc., have been routinely used for synthesis of nano-particles. Till date, the research in the field of bio synthesis mainly focused on $\mathrm{Ag} \mathrm{Nps}$ (7,699 papers, 59\%), Au Nps (4,640 papers, 36\%) and $\mathrm{ZnO} \mathrm{Nps}$ (690 papers, 5\%) which help in pollution remediation using several processes such as degradation of dyes, nano adsorption etc.

of the Tonk district in Rajasthan is hot and dry. In summers the temperature goes as high as 45 degree Celsius while in winters it remains at 22 degree Celsius. The average rainfall of this area is $400 \mathrm{~mm}$.

As per 2011 census, the town has a population of 165294 souls in 45 municipal wards. The population of the town is projected as per guidelines of Central Public Health and Environment Engineering Organisation (CPHEEO) taking average of projected population by all the four methods. The water demand for year 2011 comes to be 25.62 MLD.

\section{MATERIALS AND METHODS}

\subsection{Soxhlet Apparatus:}

A Soxhlet extractor laboratory apparatus invented in 1879 by Franz von Soxhlet. It was originally designed for the purpose of extraction of a lipid from a solid material. Typically, a Soxhlet extraction is of use when the desired compound has a limited solubility in solvent, and that impurity is insoluble in solvent. It allows for unmonitored and unmanaged operation while efficiently recycling a small amount of solvent to dissolve a larger amount of material.

\subsection{Sonicator}

Sonication is the act of applying sound energy to agitate particles in a sample, for various purposes such as the extraction of multiple compounds from plants, microalgae and seaweeds. Ultrasonic frequencies $(>20 \mathrm{kHz})$ are usually used, leading to the process also being known as ultrasonication or ultrasonication.

\subsection{Spectrophotometer}

The spectrophotometer is an instrument which measures an amount of light that a sample absorbs. The spectrophotometer works by passing a light beam through a sample to measure the light intensity of a sample. 


\subsection{Photocolorimeter}

A colorimeter is a device used in colorimetry. In scientific fields the word generally refers to the device that measures the absorbance of particular wavelength of light by a specific solution. This device is commonly used to determine the concentration of a known solute in a given solution by the application of the Beer-Lambert law, which states that the concentration of a solute is proportional to the absorbance.

\subsection{Preparation Of Plant Extract:}

$>$ The leaves sample of Chikku Plant (Manilkara zapota) was dried and powdered.

$>50 \mathrm{~g}$ of powdered sample was weighed and placed in thimble tube of Soxhlet apparatus. Absolute Methanol was used to obtain crude extract from the plant sample. The soxhlet was run at $650 \mathrm{C}$ for twelve cycles, each cycle spanning about 30-40 $\min$

$>$ Once all the cycles were completed power was switched off but supply of water was provided for around 20 minutes so that complete condensation can take place.

$>$ After that apparatus was allowed to cool for 1-2 hours.

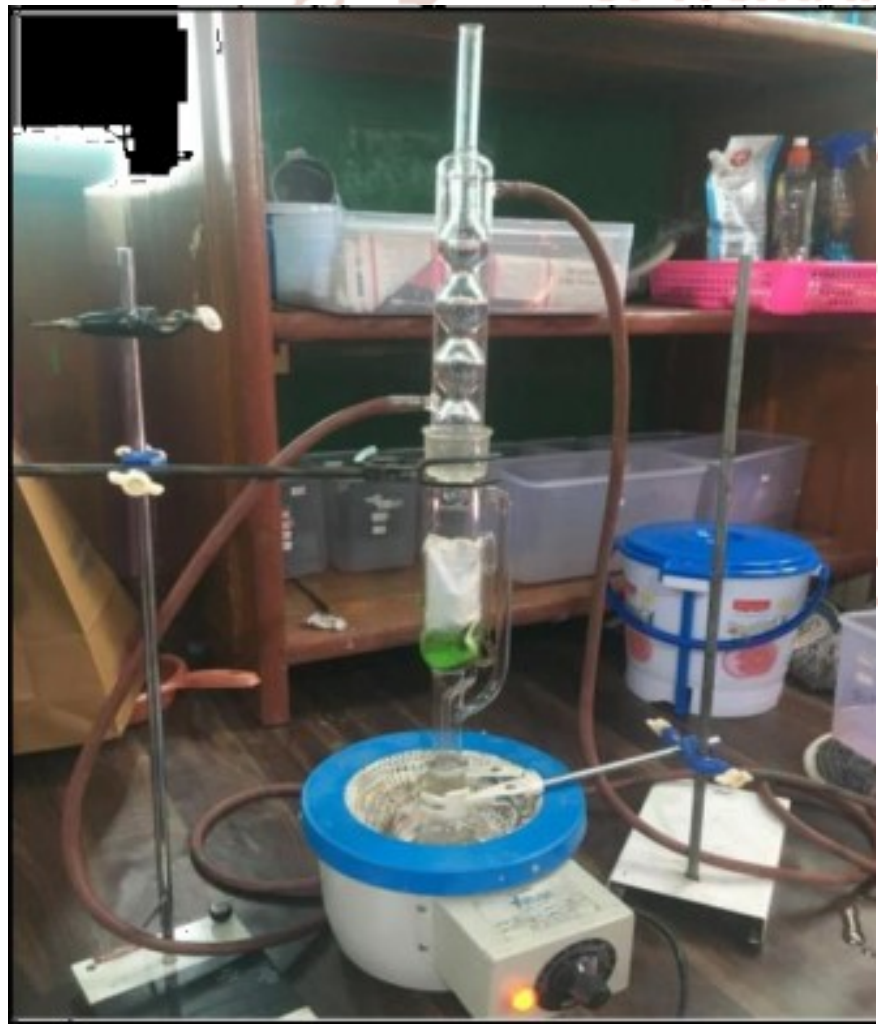

Figure 2.1: Showing extraction of plant extract using Soxhlet Apparatus

$>$ After that plant extract from round bottom flask was poured in petri plates and left overnight.

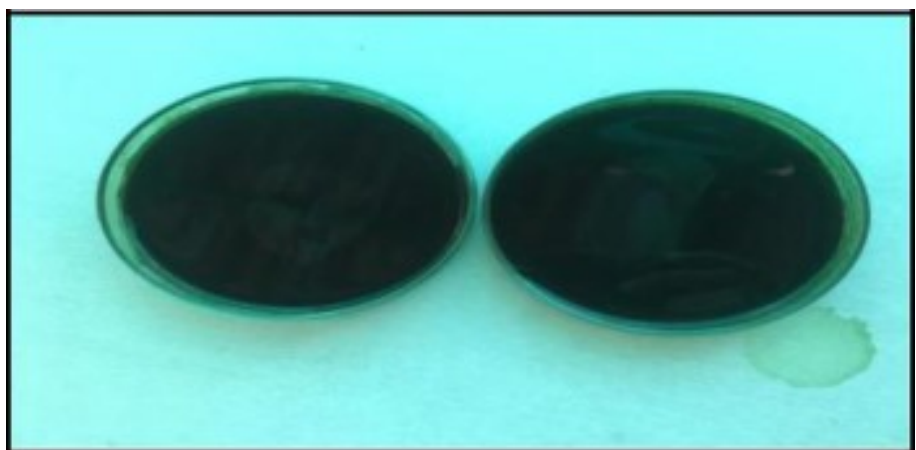

Figure 2.2: Plant extract poured in petri plates

$>$ The plant extract obtained in the form of the paste was measured on weighing balance which weighed $0.36 \mathrm{~g}$.

Around $0.30 \mathrm{~g}$ of plant extract was taken and dissolved in $3 \mathrm{ml}$ of DMSo (as plant extract dissolves properly in DMSo as compared to water. Now $57 \mathrm{ml}$ of water was added to make the solution $60 \mathrm{ml}$.

Further, $3 \mathrm{mM}$ of $50 \mathrm{ml}$ of Fe2O3 was prepared by adding $0.23 \mathrm{~g}$ of $\mathrm{Fe} 2 \mathrm{O} 3$ in $50 \mathrm{ml}$ of distilled water.

Then, plant extract solution was mixed with $3 \mathrm{mM}$ of $50 \mathrm{ml}$ of $\mathrm{Fe} 2 \mathrm{O} 3$ and heated till volume becomes approximately half.

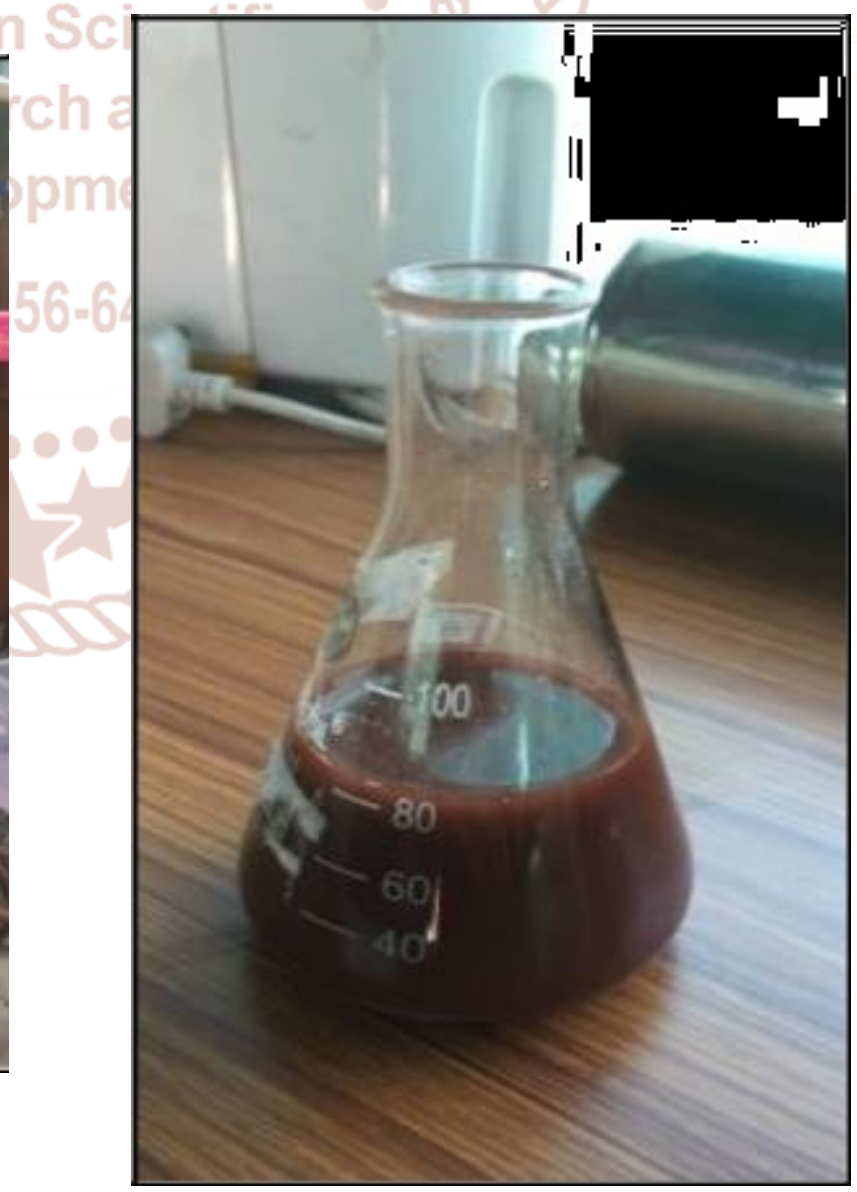

Figure 2.3: Mixture of plant extract and Fe2O3 
$>$ It was stored in dark room for one day.

$>$ Next day, it was placed in sonicator for 30 minutes that is for 4 cycles each of 480 seconds so that sonic waves makes the nanoparticles to spread uniformaly.

$>$ It was again stored in dark room for one day.

$>$ Then the mixture was poured in petriplates and left for an overnight. Next day, paste formed in petriplates was scraped which weighed around $370 \mathrm{mg}$.

$>$ It was dissolved in $10 \mathrm{ml}$ of distilled water and was stored properly.

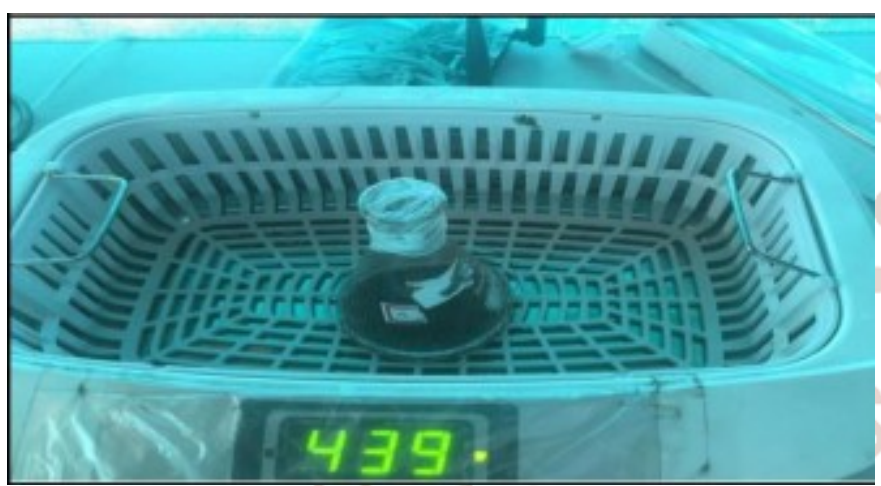

Figure 2.4: Sonicator

\subsection{UV-VIS Spectroscopy Analysis:}

$>$ UV-VIS analysis was done by UV-VIS spectrophotometer.
The reaction mixture was diluted $1.0 \mathrm{ml}$ of sample to $4 \mathrm{ml}$ of water.

The reaction mixture obtained was monitored in UV-VIS spectrophotometer and was read absorbance ranging from $380-500 \mathrm{~nm}$. At 380 it has shown the highest peak.

\begin{tabular}{|c|c|}
\hline $\begin{array}{c}\text { Wavelength of } \\
\text { monitoring }\end{array}$ & $\begin{array}{c}\text { Absorbance } \\
\text { value }\end{array}$ \\
\hline $360 \mathrm{~nm}$ & $\mathbf{0 . 9 0 1}$ \\
\hline $380 \mathrm{~nm}$ & $\mathbf{1 . 0 4 3}$ \\
\hline $400 \mathrm{~nm}$ & $\mathbf{0 . 9 6 9}$ \\
\hline $420 \mathrm{~nm}$ & $\mathbf{0 . 9 1 6}$ \\
\hline $440 \mathrm{~nm}$ & $\mathbf{0 . 8 6 2}$ \\
\hline $460 \mathrm{~nm}$ & $\mathbf{0 . 7 8 8}$ \\
\hline $480 \mathrm{~nm}$ & $\mathbf{0 . 7 5 9}$ \\
\hline $500 \mathrm{~nm}$ & $\mathbf{0 . 7 1 8}$ \\
\hline
\end{tabular}

The reaction mixture obtained after heating was monitored in UV-VIS spectrophotometer and was read absorbance ranging from $350-560 \mathrm{~nm}$.

\subsection{SEM and TEM Analysis:}

For the confirmation test of nano particle formation, the sample was sent for SEM \& TEM analysis.

\subsection{Treatment of Dye Sample Using Synthesized Nano particles:}

Table 2.2:Preparation of Control and Test Samples

Total 9 test tubes were prepared in 3 sets:

\begin{tabular}{|c|c|c|}
\hline & Content & Concentration \\
\hline 1. & Methlene blue+ distilled water+Plant synthesised NP & $4 \mathrm{ml}+2 \mathrm{ml}+1 \mathrm{ml}$ \\
(Test tube 1) & $\begin{array}{c}\text { (Test tube-2) } \\
\text { 2. }\end{array}$ & Eosin Yellow+ distled water+ Plant sysed NP \\
\hline 3. & $\begin{array}{c}\text { Industrial Sample+ distilled water+ Plant synthesised NP } \\
\text { (Test Tube-3) }\end{array}$ & $4 \mathrm{ml}+2 \mathrm{ml}+1 \mathrm{ml}$ \\
\hline 4. & $\begin{array}{c}\text { Ethylene blue+ distilled water Control } \\
\text { (Test tube-4) }\end{array}$ & $4 \mathrm{ml}$ \\
\hline 5. & $\begin{array}{c}\text { Eosin Yellow+ distilled water Control } \\
\text { (Test tube-5) }\end{array}$ & $4 \mathrm{ml}$ \\
\hline 6. & $\begin{array}{c}\text { Industrial Sample+ distilled water Control } \\
\text { (Test tube-6) }\end{array}$ & $4 \mathrm{ml}$ \\
\hline
\end{tabular}

All 9 test tubes were sonicated for 30 minutes for proper mixing of the mixture and were stored in a dark room for 48 hours. 


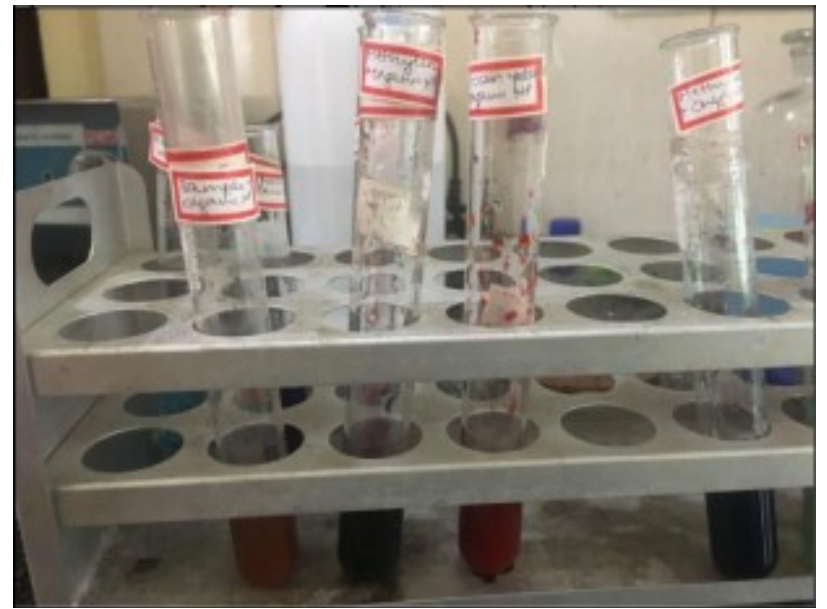

It has shown peak at $380 \mathrm{~nm}$ which shows that preliminary test has shown that nano particles are formed.

Figure 2.5: Dyes containing Plant extracted N

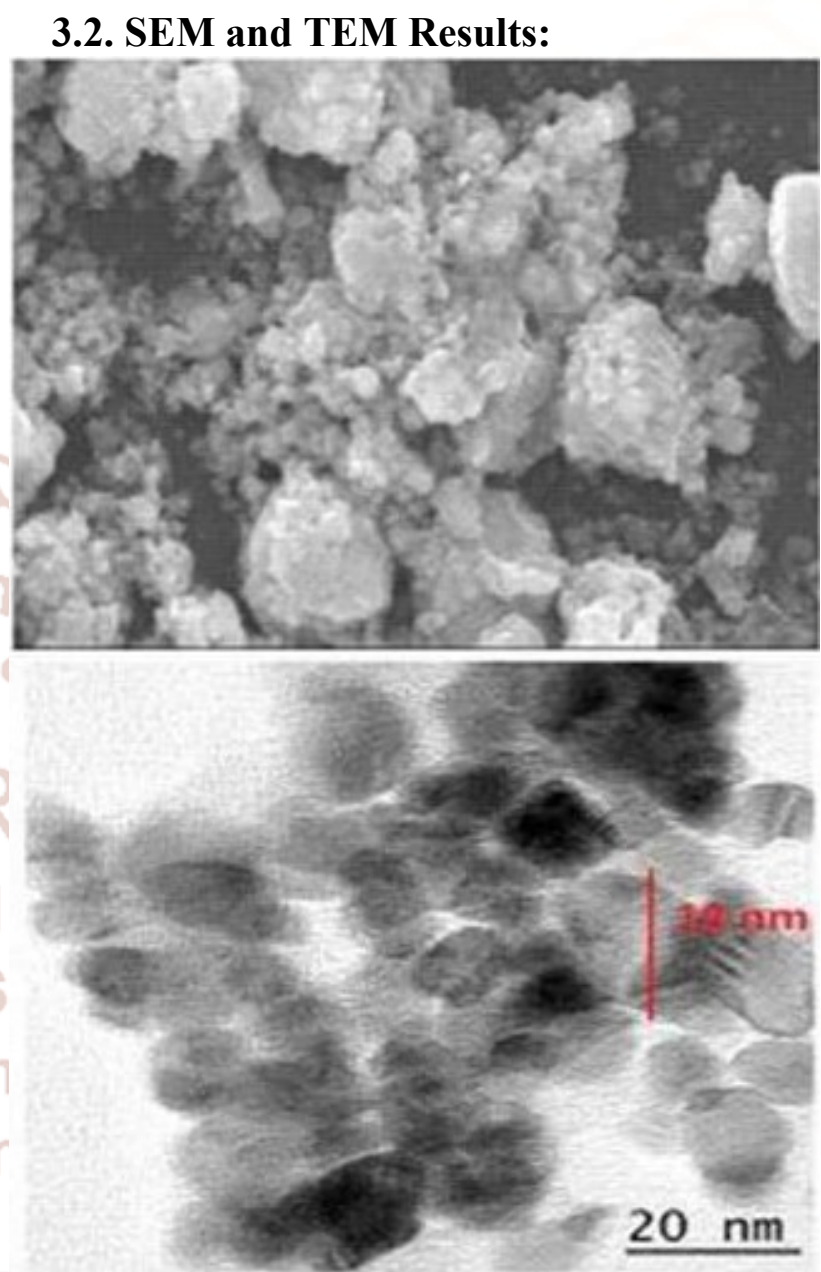

Figure 3.2: Left to right: Shape, size of nanoparticles chapter.

\subsection{UV-VIS Spectroscopy Analysis For Plant Synthesised Nanoparticles:}

The readings obtained from UV-VIS spectrophotometer were represented by plotting a graph as shown

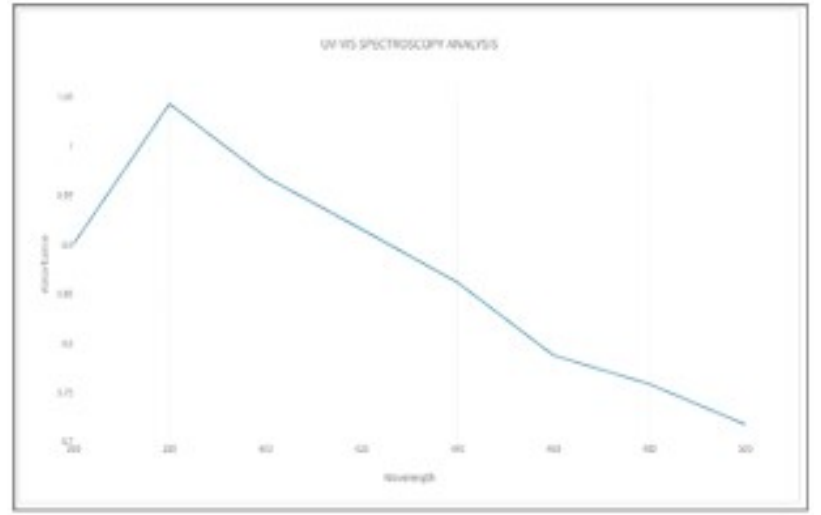

\subsection{Nano Particle Effect On Dyes:}

Ferric oxide nano particles were prepared chemically as well as using plant extract of chikku leaves using soxhlet apparatus. These nano particles were tested on eosin yellow dye, methylene blue dye and an industrial sample by adding $1 \mathrm{ml}$ of prepared nano particles. After different time intervals results were observed.

Photocolorimeter and spectrophotometer was used to analyse eosin yellow sample at $520 \mathrm{~nm}$ and methylene blue sample at $620 \mathrm{~nm}$ whereas spectrophotometer was used to analyse industrial sample after finding out the lambda max as as what dyes were used in industrial sample was not known hence wavelength at which the sample will show maximum wavelength cannot be determined without finding lambda max.

Figure 3.1: Graph for plant synthesized nano particle 
International Journal of Trend in Scientific Research and Development (IJTSRD) ISSN: 2456-6470

\subsubsection{Lambda Max Calculation for Industrial Sample:}

In order to find lambda max, readings were taken for industrial sample control between visible wavelengths that is $400-700 \mathrm{~nm}$ after diluting the industrial sample control using distilled water $(1200 \mu \mathrm{l}$ of distilled water in $200 \mu \mathrm{l}$ industrial sample control). Following readings were observed in spectrophotometer:

Table3.1: Readings for calculation of Lambda max

\begin{tabular}{|l|l|}
\hline \multicolumn{1}{|c|}{ Wavelength(nm) } & \multicolumn{1}{|c|}{ Readings } \\
\hline 420 & 0.022 \\
\hline 440 & 0.015 \\
\hline 460 & 0.015 \\
\hline 480 & 0.019 \\
\hline 500 & 0.025 \\
\hline 520 & 0.031 \\
\hline 540 & 0.020 \\
\hline 560 & 0,024 \\
\hline 580 & 0.035 \\
\hline 600 & 0.044 \\
\hline 620 & 0.058 \\
\hline 640 & 0.063 \\
\hline 660 & 0.043 \\
\hline 680 & 0.017 \\
\hline 700 & 0.008 \\
\hline
\end{tabular}

Since maximum value of wavelength is seen at 640 $\mathrm{nm}$ therefore it becomes lambda max and all the readings for industrial sample were taken on $640 \mathrm{~nm}$.

\subsection{Results After 48 Hours (2 Days):}

3.4.1. Results for Methylene blue:

Table 3.2: \% Reduction in Methylene Blue After 2 Days

\begin{tabular}{|c|c|c|}
\hline Dye & $\begin{array}{l}\text { OD at } \\
620 \mathrm{~nm}\end{array}$ & $\%$ Reduction \\
\hline $\begin{array}{l}\text { Methylene Blue } \\
\text { Control }\end{array}$ & 1.05 & - \\
\hline $\begin{array}{l}\text { Methylene Blue }+ \\
\text { Plant Extracted NP }\end{array}$ & 0.37 & 64.7 \\
\hline
\end{tabular}

\subsubsection{Results for eosin yellow:}

Table 3.3.: \% Reduction In Eosin Yellow After 2 Days

\begin{tabular}{|c|c|c|}
\hline Dye & $\begin{array}{l}\text { OD at } \\
520 \mathrm{~nm}\end{array}$ & $\%$ Reduction \\
\hline $\begin{array}{ll}\text { Eosin } & \text { Yellow } \\
\text { Control } & \end{array}$ & 2.865 & - \\
\hline $\begin{array}{l}\text { Eosin Yellow + } \\
\text { Plant extracted NP }\end{array}$ & 1.885 & 34.20 \\
\hline
\end{tabular}

3.4.3 Results for Industrial sample:

Table 3.4: \% Reduction in Industrial Sample

\begin{tabular}{|c|c|c|}
\hline Dye & $\begin{array}{l}\text { OD at } \\
640 \mathrm{~nm}\end{array}$ & $\%$ Reduction \\
\hline $\begin{array}{ll}\text { Ind. } & \text { Sample } \\
\text { Control } & \end{array}$ & 0.063 & - \\
\hline $\begin{array}{l}\text { Ind. Sample }+ \\
\text { Plant extracted NP }\end{array}$ & 0.044 & 30.15 \\
\hline
\end{tabular}

\subsection{Results after 120 Hours (5 Days):}

\subsubsection{Results for Methylene Blue:}

Table 3.5.: \% Reduction in Methylene Blue after 5

\begin{tabular}{|l|l|l|}
\multicolumn{1}{|c|}{ days } \\
\hline \multicolumn{1}{|c|}{ Dye } & $\begin{array}{c}\text { OD at } \\
620 \mathrm{~nm}\end{array}$ & \% Reduction \\
\hline $\begin{array}{l}\text { Methylene Blue } \\
\text { Control }\end{array}$ & 1.10 & - \\
\hline $\begin{array}{l}\text { Methylene Blue }+ \\
\text { Plant Extracted NP }\end{array}$ & 0.30 & 72.7 \\
\hline
\end{tabular}

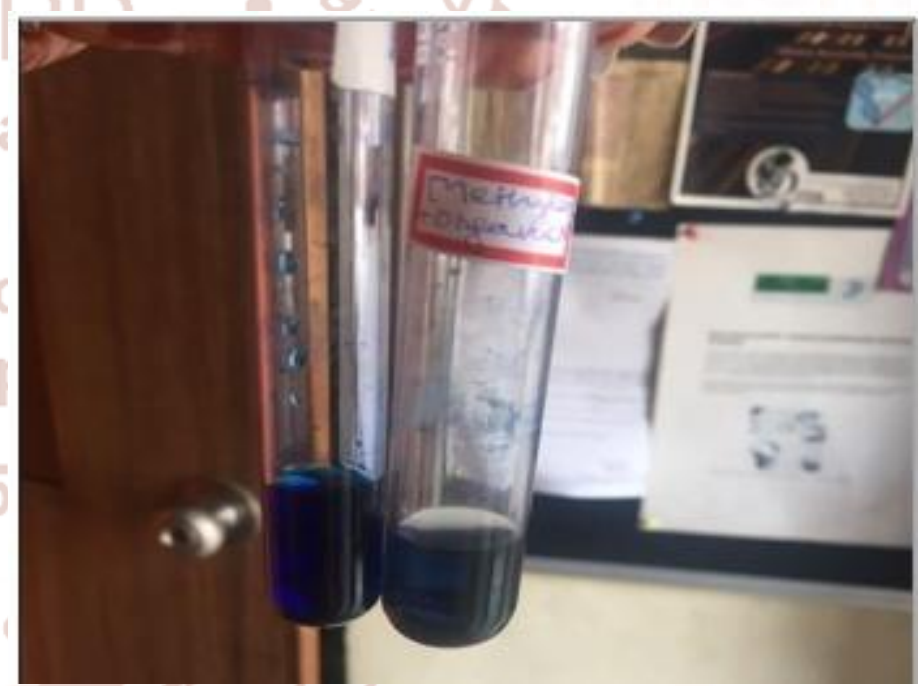

Figure 3.3.: Change of colour during treatment of MB after 5 days ( left to right: Control, Ind. MB + NP)

\subsubsection{Results for Eosin Yellow:}

Table 3.6.: \% Reduction in Eosin Yellow after 5 days

\begin{tabular}{|l|l|l|}
\hline \multicolumn{1}{|c|}{ Dye } & $\begin{array}{c}\text { OD at } \mathbf{5 2 0} \\
\text { nm }\end{array}$ & $\begin{array}{c}\% \\
\text { Reduction }\end{array}$ \\
\hline Eosin Yellow Control & 1.62 & - \\
\hline $\begin{array}{l}\text { Eosin Yellow + Plant } \\
\text { Extracted NP }\end{array}$ & 0.54 & 66.6 \\
\hline
\end{tabular}


International Journal of Trend in Scientific Research and Development (IJTSRD) ISSN: 2456-6470

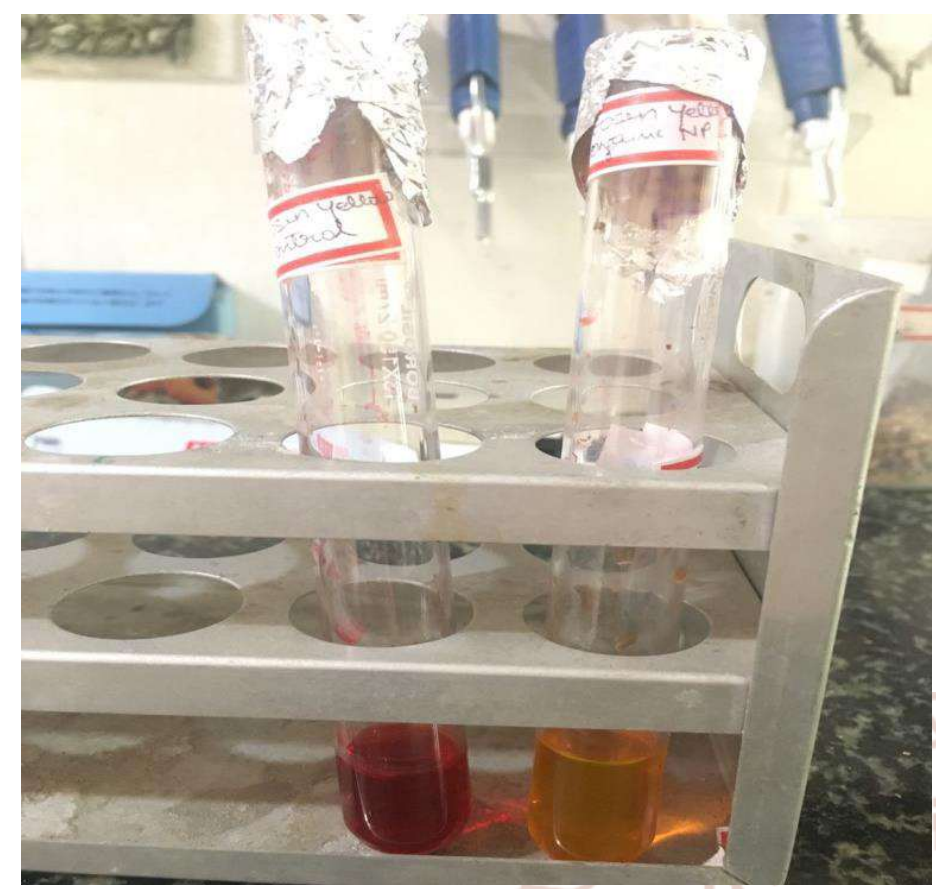

3.6. Results after 168 Hours (7 Days):

3.6.1. Results for Methylene Blue:

Table 3.8.: \% Reduction in MB after 7 days

\begin{tabular}{|c|c|c|}
\hline Dye & $\begin{array}{c}\text { OD at } 620 \\
\mathrm{~nm}\end{array}$ & $\begin{array}{c}\% \\
\text { Reduction }\end{array}$ \\
\hline $\begin{array}{l}\text { Methylene } \quad \text { Blue } \\
\text { Control }\end{array}$ & 0.809 & - \\
\hline $\begin{array}{l}\text { Methylene Blue }+ \\
\text { Plant Extracted NP }\end{array}$ & 0.121 & 85 \\
\hline
\end{tabular}

Figure 3.4.: Change of colourafter 5 days during treatment of EY (left to right: Control, EY + NP)

\subsubsection{Results for Industrial Sample:}

Table 3.7.: \% Reduction in Industrial Sample After 5 days

\begin{tabular}{|c|c|c|}
\hline Dye & $\begin{array}{c}\text { OD at } 640 \\
\mathrm{~nm}\end{array}$ & $\begin{array}{c}\% \\
\text { Reduction } \\
\end{array}$ \\
\hline $\begin{array}{ll}\text { Industrial } & \text { Sample } \\
\text { Control } & \end{array}$ & 0.159 & \\
\hline $\begin{array}{l}\text { Industrial Sample } \\
\text { Plant Extracted NP }\end{array}$ & 0.053 & 66.6 \\
\hline
\end{tabular}

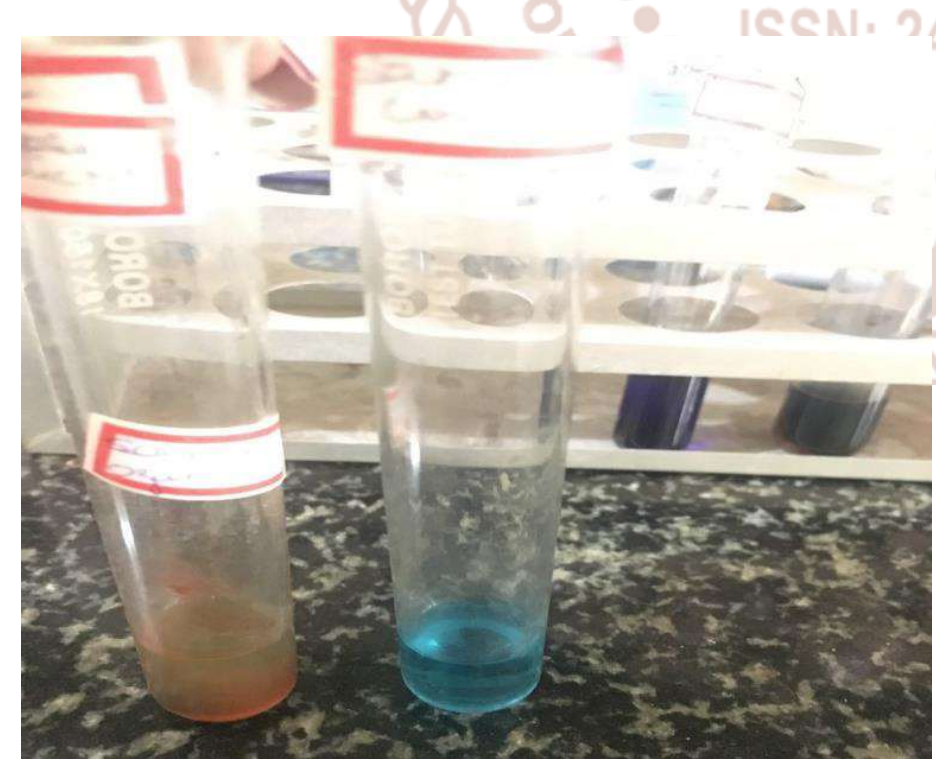

Figure 3.5.: Change of colour after 5 days during treatment of IS ( left to right: Ind. Sample + NP, Control)

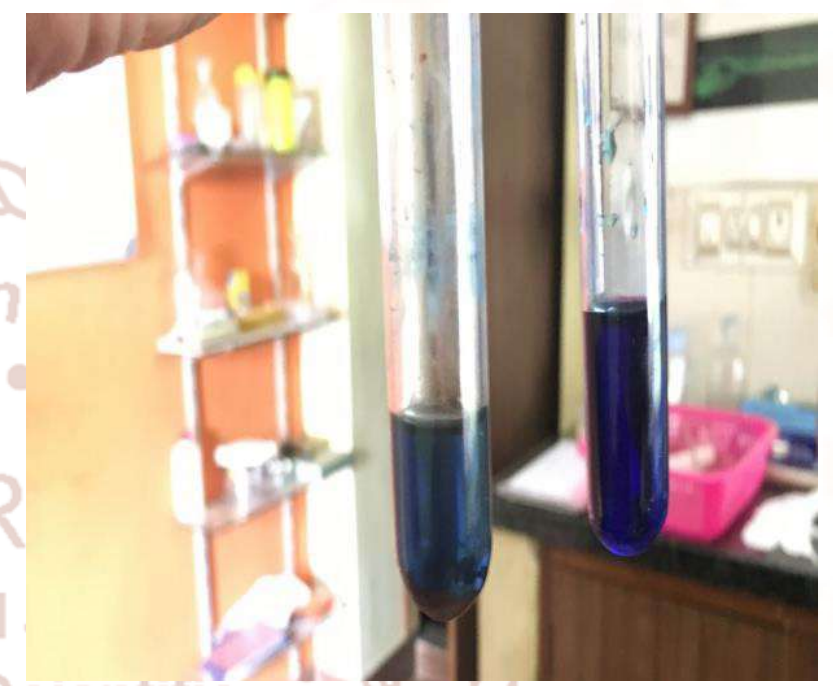

Figure 3.6.: Change of colour after 7 days during treatment of MB (left to right: $\mathrm{MB}+\mathrm{NP}$, Control)

\subsubsection{Results for Eosin Yellow:}

Table 3.9.: \% Reduction in EY After 7 days

\begin{tabular}{|l|l|l|}
\hline \multicolumn{1}{|c|}{ Dye } & $\begin{array}{c}\text { OD at 520 } \\
\text { nm }\end{array}$ & \multicolumn{1}{c|}{$\begin{array}{c}\% \\
\text { Reduction }\end{array}$} \\
\hline Eosin Yellow Control & 1.52 & - \\
\hline $\begin{array}{l}\text { Eosin Yellow + Plant } \\
\text { Extracted NP }\end{array}$ & 0.26 & 82 \\
\hline
\end{tabular}

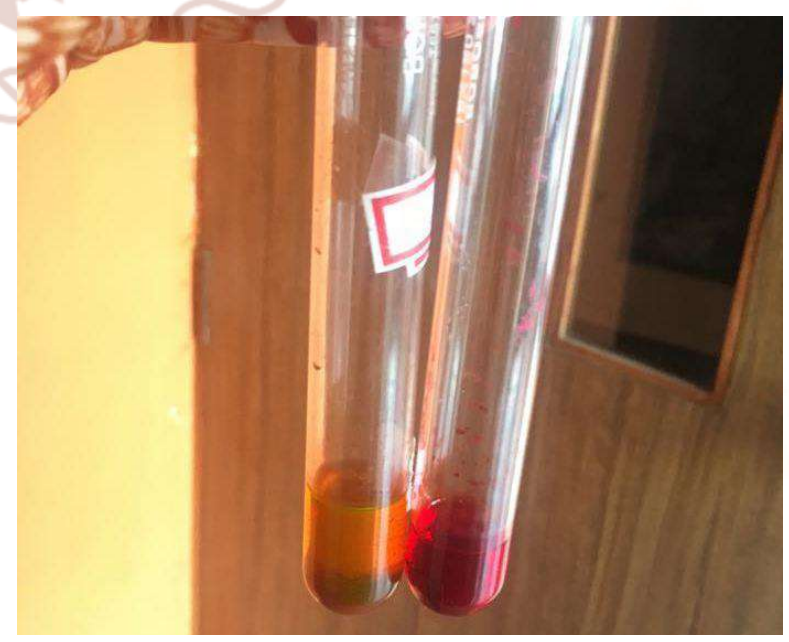

FIGURE3.7.: Change of colour after 7 days during treatment of EY( left to right: EY + NP, Control) 
International Journal of Trend in Scientific Research and Development (IJTSRD) ISSN: 2456-6470

\subsubsection{Results for Industrial sample:}

Table3.10: \% Reduction in Industrial Sample After 7 days

\begin{tabular}{|c|c|c|}
\hline Dye & $\begin{array}{l}\text { OD at } 640 \\
n m\end{array}$ & $\begin{array}{c}\% \\
\text { Reduction }\end{array}$ \\
\hline Eosin Yellow Control & 0.122 & - \\
\hline $\begin{array}{l}\text { Eosin Yellow }+ \text { Plant } \\
\text { Extracted NP }\end{array}$ & 0.014 & 88.5 \\
\hline
\end{tabular}

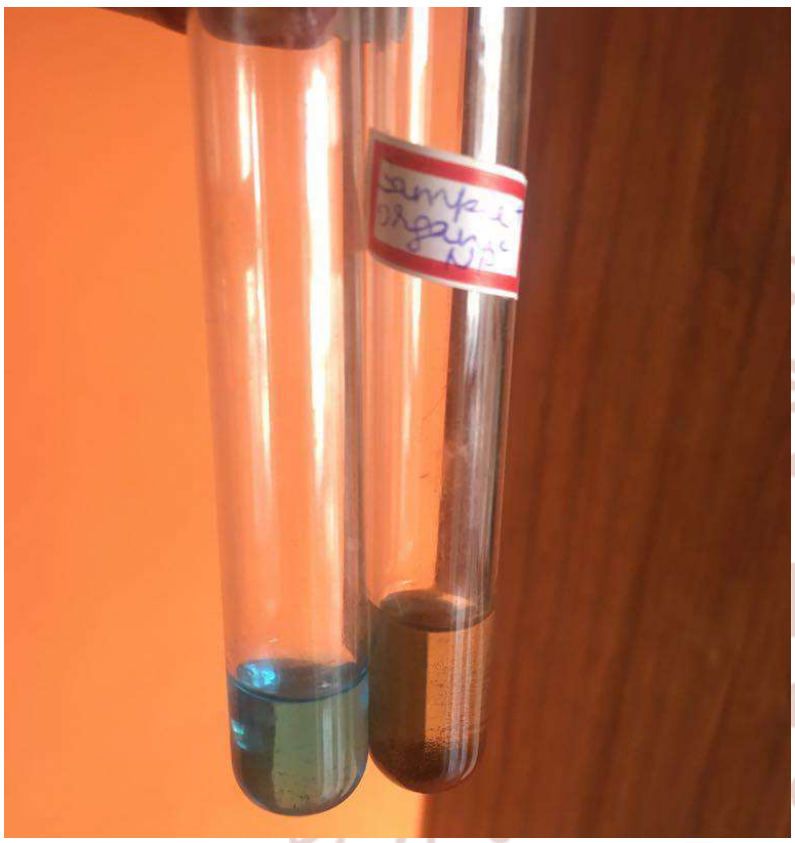

Figure3.8.: Change of colour after 7 days during treatment of IS( left to right: Ind. Sample Control + Ind. Sample + NP)

\subsection{Result Overview (\% Reduction):}

Table 4.11: Overall reduction

\begin{tabular}{|l|l|l|l|}
\hline \multicolumn{1}{|c|}{ Dye } & $\begin{array}{c}\% \\
\text { Reduction } \\
\text { after } \\
48 \text { hrs (2 } \\
\text { days) }\end{array}$ & $\begin{array}{c}\text { \%eduction } \\
\text { after } \\
120 \text { hrs (5 } \\
\text { days) }\end{array}$ & $\begin{array}{c}\% \\
\text { Reduction } \\
\text { after } \\
168 \text { hrs (7 } \\
\text { days) }\end{array}$ \\
\hline $\begin{array}{l}\text { Methylene } \\
\text { Blue + Plant } \\
\text { extracted NP }\end{array}$ & $64.7 \%$ & $72.7 \%$ & $85 \%$ \\
\hline $\begin{array}{l}\text { osin Yellow } \\
+\quad \text { Plant } \\
\text { extracted NP }\end{array}$ & $34.20 \%$ & $66.6 \%$ & $82.8 \%$ \\
\hline $\begin{array}{l}\text { ndustrial } \\
\text { Sample } \\
+ \text { Plant } \\
\text { extracted NP }\end{array}$ & $30.15 \%$ & $66.6 \%$ & $88.5 \%$ \\
\hline
\end{tabular}

\section{III.CONCLUSION}

The study involves the experimentation of treatment of dyes from textile industries For this purpose magnetic oxide nano particles were extracted from
Manilkara Zapota (Chikku) leaves using soxhlet apparatus and was prepared chemically as well. During these experiments effect of nano particles on different dyes like methylene blue, eosin yellow and industrial sample were also recorded. The data were analyzed and the major conclusions and recommendations for future work are listed in this chapter:

1. After addition of nano particles in the dye samples they were stored in dark room for 48 hours and on taking their OD after 48 hours, methylene blue showed $64.7 \%$ reduction, eosin yellow showed $34.20 \%$ reduction whereas industrial sample showed $30.15 \%$ reduction on addition of nano particles extracted from plant leaves.

2. Next readings were taken after 120 hours i.e. 3 days. The reduction percent increased to $72.7 \%$ in case of methylene blue, $66.6 \%$ in case of eosin yellow and industrial sample. This shows nano particle is working efficiently with time.

3. Maximum efficiency of $85 \%$ in case of methylene blue, $82.8 \%$ in case of eosin yellow and $88.5 \%$ in case of industrial sample was achieved after 168 hours ( 7 days)

4. It was observed that increase in detention time had resulted in an increase in dye reduction efficiencies.

5. Further it was observed that when readings were taken after 216 hours i.e. after 9 days, there was no considerable change in readings that is reduction percent was almost constant. This shows that nano particles had reached its maximum capacity to reduce the dye concentration.

6. A residue was observed in each test tube containing dye in which nano particles were added, which further shows that nano particles got settled down at the bottom of the test tubes which make their separation easier.

7. The highest reduction was shown in industrial sample followed by methylene blue and eosin yellow.

8. Considerable colour change was observed in all the three dyes with passage of time which is also shows that dye reduction has taken place.

9. Treatment of dye using Ferric oxide nano particle can be a promising method as compared to other conventional method if carried out on a large scale. 
International Journal of Trend in Scientific Research and Development (IJTSRD) ISSN: 2456-6470

\section{IV.FUTURE RECOMMENDATIONS}

1. The effect of ferric oxide nano particle should be tested on other dyes used in textiles as well as other industries.

2. Effect on percent reduction in dyes should be experimented by adding different concentration of ferric oxide nano particles and at what concentration the nano particle showed highest percent reduction should be recorded.

3. Different methods for removal of ferric oxide nano particles after treatment of waste water should be tested and it should be analysed which is the best suited method for nano particle removal.

4. Pilot scale studies should be carried out to check the efficiency of the process along with its cost effectiveness.

5. Other plants should be used to produce ferric oxide nano particles and should be analysed which is the best plant for extraction of ferric oxide nano particles.

\section{REFERENCES}

1. Abdolmohammad-Zadeh, H., Ghorbani, E., \& Talleb, Z. (2013). Zinc-aluminum layered double hydroxide as a nano-sorbent for removal of Reactive Yellow 84 dye from textile wastewater effluents.

2. Journal of the Iranian Chemical Society.

3. Abraham, T. E., Senan, R. C., Shaffiqu, T. S., Roy, J. J., Poulose, T. P., \& Thomas, P. P. (2003).

4. Adesina, A. A. (2004). Bioremediation of textile azo dyes by an aerobic bacterial consortium using a rotating biological contactor. Biotechnology Progress,

5. Industrial exploitation of photocatalysis: Progress, perspectives and prospects. Catalysis Surveys from Asia (2010).

6. Paul, R., Wolf, J., Herbert, P., Sinkula, M.,(2003) .investing in nanotechnology.

7. Begam, N. A., Mandal, S., Basu, laskar, R. A., Mandal, D (2009). colliods and surfaces" B; bio interfaces.

8. M.C.Rocco, Broader societal issue of nanotechnology, journal of nanoparticle research, 2003.

9. Westerfield, M, the zebrafish book, University of Orgeon press, eugene, orgeon., 2000.
10. Monalisa Pattanayak and P.L. Nayak (2012). Ecofriendly green synthesis of iron nano particles from various plants and spices extract.

11. Monalisa Pattanayak and P.L. Nayak (2013). Green synthesis and characterization of zero valent iron nano particles from leaf extract of neem.

12. Mihir Herlekar, Siddhivinayak Barve and Rakesh Kumar (2014). Plant mediated green synthesis of iron nano particles.

13. Kartik H. Gonawala and Mehali J. Mehta (2014). Removal of colour from different dye waste water by using ferric oxide as an adsorbent.

14. Arafat A. and Sabrin A. Samad (2015). Textile dye removal from waste water effluents using Chitosan-ZnO nano composite.

15. Pawan Kaur, Rakesh Thakur and Ashok Choudhary (2016). Biogenesis og Copper nano particles using peel extract of Punica Granatum and their antimicrobial activity against opportunistic pathogens.

16. Muzzamil Anjum and R. Mianand (2016). Remediation of waste water using various nano particles.

17. Ibrahim Khan, Khalid Saeed and Idress Khan (2017). Nano particles: Properties, applications and toxicities.

18. S. Kanagasubbulakshmi and K. Kadirvelu (2017). Green synthesis of ferric oxide nano particles using Lagenaria Siceraria and evaluation of its antimicrobial activity.

19. P. Senthil Kumar, Abhishek S. Narayan and Abhishek Dutta (2018). Nano chemicals and effluent treatment in textile industry.

20. Tim Robinson (2001). Remediation of dyes in textile effluent.

21. Metal Nano particles: Synthesis, Characteristics and application by Daniel L. Fedlhem.

22. Nanostructures and nano materials by Guozhong Cao.

23. Handbook of Nanomaterial properties by Bharat Bhushan.

24. Gregory P. Azo dyes: Structure-carcinogenicity relationships. Dyes Pigments 1986.

25. Phalakornkule C., Polgumhang S., and Tongdaung W.(2009). Performance of an process in Treating 
Direct Dye: World Academy of Science, 34. Kothuis B and Schelleman F (1995) Rough Engineering and Technology 57.

Overview of the Textiles Industry and the

26. Abraham, R. and Freeman, H.S. (1996). Environmental chemistry of dyes and pigments. Canada: John Wiley \& Sons. Inc.

27. Benefield, L. D., Judkins J. F. and Weand, B. L. (1982). Process Chemistry for Water and Wastewater Treatment.

28. Cooper S G (1978) The Textile Industry. Environmental Control and Energy Conservation. Noyes Data Corporation, New Jersey, USA.

29. C. Terras, P. Vandevivere, W. Verstraete (1999), Optimal treatment and rational reuse of water in textile industry, Water Sci. Technol.

30. EPA, a SITE Superfund Innovative Technology Evaluation: EPA/640/S-937504. EPA, a SITE Superfund.

31. G.F. Babuna, B. Soyhan, G. Eremektar, D. Orhon(1999). Evaluation of treatability for two textile mill effluents.

32. J.P. Lorimer, T.J. Mason, M. Plattes, S.S. Phull, D.J. Walton (2001).Degradation of dye effluent.

33. K. Rajeshwar, J.G. Ibanez, G.M. Swai (1999). Environment. Discussion paper for the Workshop on Biotechnology for Cleaner Production, Institute for Applied Environmental Economics, The Netherlands.

35. Laing I G (1991). The Impact of Effluent Regulations on the Dyeing Industry. Review in Progress Coloration.

36. S. Karcher, A. Kornmuller, M. Jekel (1999). Removal of reactive dyes by sorption/ complexation with cuculbituril.

37. Steffen Robertson and Kirsten (1993).Water and Waste-Water Management in the Textile Industry. Water Research Commission, Pretoria, South Africa.

38. Swedish Environmental Protection Agency (1989) The Textile Industry Fact Sheet. Report No. 071SNV / Br SNV 20610.

39. Y.M. Slokar, A.M.L. Marechal (1998). Methods of decoloration of textile wastewaters, Dye Pigments.

40. Lakshmanan D, Clifford D, Samanta G (2009) Environ Sci Technol. Electrochemistry and the environment, J.Appl. Electrochem. 